\title{
EXPERIMENTAL BACTERIAL ENDOCARDITIS WITH SPECIAL REFERENCE TO CLINICAL A.SPECTS
}

\author{
ITTAKU MIKATA* \\ Department of Internal Medicine, School of Medicine \\ Keio University
}

(Received on July 1, 1958)

INTRODUCTION

My college and I have studied particularly infectious diseases, especially subacute bacterial endocaritis clinically during the past ten years. We have tried to understand what the subacute bacterial endocarditis was more thoroughly from findings of the experimental endocarditis.

In this report, I try to discuss pathogenesis of bacterial endocarditis as indicated by the findings of our animal experiments, and then to show the correlation between the findings in experimental endocarditis and those in human endocarditis.

\section{PATHOGENESIS OF BACTERIAL ENDOCARDITIS}

a) Experiments to Find the Most Suitable Method

In order to produce experimental endocarditis, some factors must be added to bacterial infection, such as damaging the heart valve. As shown in Table 1, we tried twelve methods to produce endocarditis and used 376 rabbits, 33 dogs, 168 rats and 580 mice in all of our experiments. As a causative microorganism, we used a strain of Streptococcus sanguis, a sub-type of streptococcus viridans group, isolated from a patient with subacute bacterial endocarditis. Among these twelve methods in Table 1, No. 3 (using organ-phosphatide), No. 9 (using anti-rabbit-heart-duckserum) and No. 5 and No. 7 (overloading on the heart) yielded comparatively successful results in producing endocarditis. The incidence was $56.8 \%, 77.9 \%, 83.5 \%, 50 \%$ respectively. From these results we feel that the factors playing leading parts in producing endocarditis are: 1) increase in work load on the heart, 2) change in the blood components, 3) virulence of the causative microorganism, 4) susceptibility of the animal to it, 5) allergic factor and so forth. Other factors can not be neglected, however, these factors have very complicated relations between each other as shown in Figure 1.

\footnotetext{
* Professor of Internal Medicine.
} 


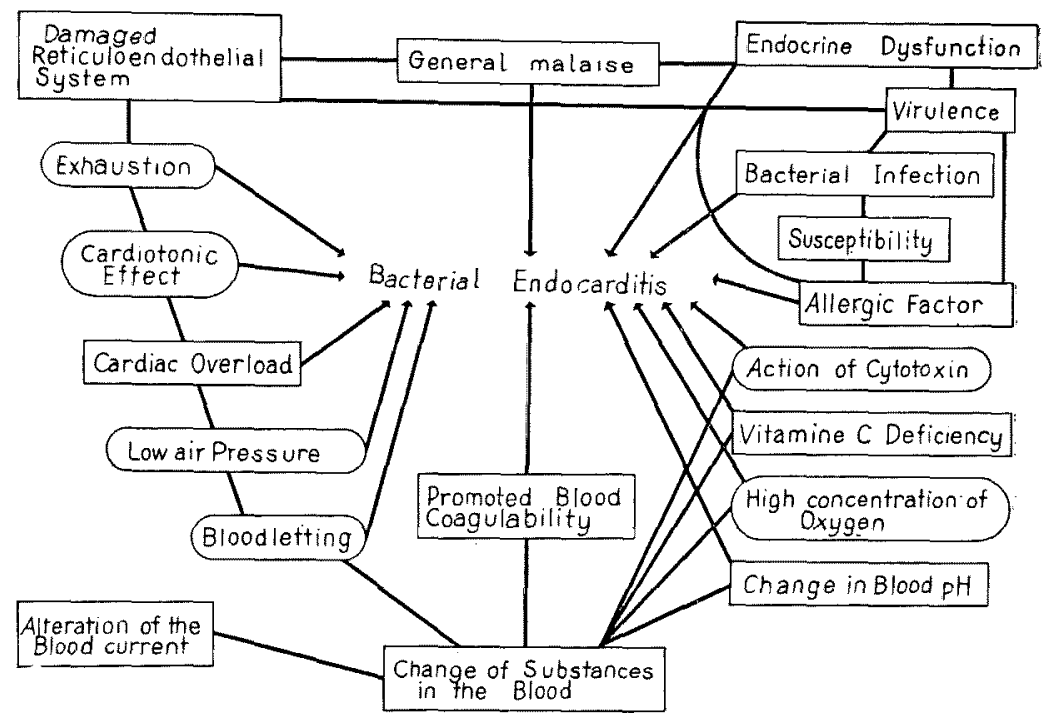

Fig. 1 Re'ationship batween bacterial endocarditis and various factors.

A particularly interesting fact was that when we tried to produce endocarditis to mice exposed to pressure as low as at 25,000 feet altitude and to normal pressure with $100 \%$ of $\mathrm{O}_{2}$, we were $100 \%$ successful. We could also produce endocarditis to $43-75 \%$ of each group which we put in low partial pressure of $\mathrm{O}_{2}$ down to $17 \%$ under normal pressure. Incidence of endocarditis under low pressure which is equal as in 42,500 feet and under $100 \%$ of $\mathrm{O}_{2}$ environment was $63 \%$. Highman and Altland and others reported that under long-lasting low pressure endocarditis is produced easily, however, from our experiments, if we put animal under low pressure for a short time, it doesn't seem to be absolutely necessary factor to produce endocarditis.

Incidence of experimental bacterial endocarditis by using bacteria alone has been rather low such as $42 \%$ in dogs and $10 \%$ in rabbits. This method is the simplest and easiest one, so we tried to improve this method, then we found the following method could produce experimental bacterial endocarditis in higher per cent. We cultured Str. sanguis in blood agar for 24 hours. Them we suspend them in normal saline and make it $4-6 \mathrm{mg} / \mathrm{cc}$. We inject above solution intravenously for five consecutive days. As shown in Table 2, all the animals injected $8 \mathrm{mg}$ died, it showed high incidence when we use 4-6 $\mathrm{mg}$ with a few death, and we were hardly successful to produce experimental bacterial endocarditis by using 1-2 $\mathrm{mg}$. They have tried to make equal amount of bacteria by using blood agar but this method is much easier because we can 
measure and control the amount of bacteria. Daily injection might be a factor which causes high incidence. This success can make further investigation quite easily.

b) Experiments on Re-infection

A rabbit with experimental endocarditis which had been produced by injections of Streptococcus sanguis and of bovine endocardial phosphatide was reinfected with the same strain after a course of over one month under treatment with penicillin. It was found dead on the next day. Autopsy revealed the following findings: a vegetation on the pulmonic ostium almost blocking the ostium; miliary white plaques of organized verruca in the right chamber wall (histologically, small healed fibrous foci); a remarkable dilatation of the right ventricle; strong evidences of congestion in the liver, spleen and kidneys; acute splenitis; pulmonary abscess and interstitial pneumonia; a cellular infiltration and necrosis in the adrenal cortex; and heavy bacteremia. The changes in the heart were complex. On the one hand, white plaques of completely organized verruca healed by penicillin therapy were seen; but on the other hand, a fresh thrombus containing many colonies of streptococcus was seen in the vegetation. This is the same as our experiences in clinical cases where both healing processes and fresh active lesions are noted in the same heart in a patient who died after treatment with antibiotics. We are, therefore, convinced that changes quite similar to those of human bacterial endocarditis could be obtained experimentally by using rabbits.

From the data obtained by the above two experiments, factors chiefly participating independently or dependently upon each other in developing endocarditis can be summarized as follows:

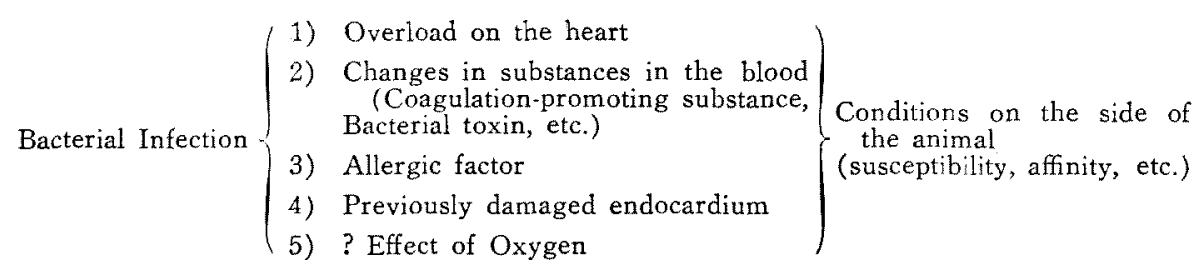

c) Effect of Cortisone

1) Histological Findings of Endocardium after Using Cortisone Alone and with Bacterial Strain:-We observed rabbits till 7th day after the administration. When we injected $5 \mathrm{mg}$ and $25 \mathrm{mg}$ of cortisone alone to rabbits, there were mild changes such as edema in endocardium and swelling of endothelium. Bacterial strain and $5 \mathrm{mg}$ of cortisone produced only early changes or 
mild degree of valvulitis but same strain and $25 \mathrm{mg}$ of cortisone could produced comparatively severe inflammation of endocardium and we could find development of bacterial verruca on the seventh day.

2) Cortisone Effect Upon Development of the Disease:-Experiments

Table 1

Experimental Endocarditis, Outline of Methods and Results of Our Experiments

\begin{tabular}{|c|c|c|c|}
\hline Method & Animal & $\begin{array}{c}\text { Incidence } \\
\text { of } \\
\text { endocarditis } \\
0\end{array}$ & $\begin{array}{l}\text { Factors likely participating in } \\
\text { producing endocarditis }\end{array}$ \\
\hline $\begin{array}{l}\text { 1. Phosphorus emulsion } \\
\text { (intraperitoneal) + Strepto- } \\
\text { coccus sanguis }\end{array}$ & Rabbit & 25.0 & $\begin{array}{l}\text { Damages of the reticuloendothel } \\
\text { system and the liver, General } \\
\text { Malaise }\end{array}$ \\
\hline $\begin{array}{l}\text { 2. Non-vitamins } \mathrm{C} \text { diet, } \\
\text { Cardiotonicus }+ \text { Str. sanguis }\end{array}$ & Rabbit & 16.7 & Vitamine $\mathrm{C}$ deficiency \\
\hline $\begin{array}{l}\text { 3. Organ phosphatide }+ \text { Str. } \\
\text { sanguis }\end{array}$ & Rabbit & 56.8 & $\begin{array}{l}\text { Promotion of blood coagulability, } \\
\text { Allergic factor }\end{array}$ \\
\hline $\begin{array}{l}\text { 4. Exposure to altitude (low } \\
\text { air pressure, rare oxygen) } \\
+ \text {-Str. sanguis }\end{array}$ & Rat & 40.0 & $\begin{array}{l}\text { Cardiac overload, Anoxid in the } \\
\text { tissue, Erythrocytosis Thrombo- } \\
\text { cytosis }\end{array}$ \\
\hline $\begin{array}{l}\text { 5. Anastomosis of the ab- } \\
\text { dominal aorta and the in- } \\
\text { ferior vena cava }\end{array}$ & Dog & 83.5 & $\begin{array}{l}\text { Alteration of the blood current, } \\
\text { Cardiac overload, Inflow of a } \\
\text { thrombus, Anoxia, Stress by a } \\
\text { surgical operation }\end{array}$ \\
\hline 6. Digitamin + Str. sanguis & Rabbit & 16.7 & $\begin{array}{l}\text { Accelerated cardiac action, a kind } \\
\text { of hyperoxia? }\end{array}$ \\
\hline $\begin{array}{l}\text { 7. Exhaustion by compulsory } \\
\text { exercises }+ \text { Str. sanguis }\end{array}$ & Rabbit & 50.0 & Cardiac overload, hypoxemia \\
\hline 8. Bloodletting + Str. sanguis & Rabbit $\quad 7$ & 14.3 & Cardiac overload, hypoxemia \\
\hline $\begin{array}{l}\text { 9. Anti-rabbit duckserum }+ \\
\text { Str. sanguis }\end{array}$ & Rabbit $\quad 104$ & 77.9 & $\begin{array}{l}\text { Allergic factor, Action of cyto- } \\
\text { toxin }\end{array}$ \\
\hline 10. Horse serum + Str. sanguis & Rabbit & 8.3 & Allergic factor \\
\hline $\begin{array}{l}\text { 11a. Str. sanguis alone } \\
\text { b. }\end{array}$ & $\begin{array}{l}\text { Rabbit } \\
\text { Dog } \\
\text { Rat }\end{array}$ & $\begin{array}{l}10.0 \\
42.3\end{array}$ & $\begin{array}{l}\text { Bacterial virulence and affinity to } \\
\text { the animal }\end{array}$ \\
\hline $\begin{array}{l}\text { 12. Raising in oxygen chamber } \\
+ \text { Str. sanguis }\end{array}$ & Rat & 100.0 & ? \\
\hline
\end{tabular}

Table 2

Incidence of Experimental Bacterial Endocarditis (E. B. E.) with Injection of Bacterial strain alone

(i.v. injections of strain of str. sanguis for five concecutive days)

\begin{tabular}{|c|c|c|c|}
\hline $\begin{array}{c}\text { Amount of Bacteria } \\
\text { strain } \\
\text { (each in jection) } \\
(\mathrm{mg})\end{array}$ & No. of rabbits & $\begin{array}{c}\text { Incidence of } \\
\text { E. B.E. } \\
(0.0)\end{array}$ & $\begin{array}{c}\text { Mortality rate } \\
\text { during the procedure } \\
(\%)\end{array}$ \\
\hline 8 & 8 & 25 & 100 \\
\hline 6 & 5 & 100 & 80 \\
\hline 4 & 4 & 100 & 0 \\
\hline 2 & 6 & 17 & 33 \\
\hline 1 & 5 & 20 & 20 \\
\hline
\end{tabular}


were performed by methods No. 3 and No. 9 (Table 1). In the latter method, $0.4 \mathrm{ml}$ of anti-rabbit-endocardial duck-serum and $0.5 \mathrm{ml}$ of living $\mathrm{Str}$. sanguis suspension were given intravenously daily for four or five days to 58 rabbits which were divided into four groups according to the methods of cortisone administration (Table 3 ).

Table 3

Dosis and Duration of Cortisone Acctate Injections in Each Group

\begin{tabular}{|c|c|c|c|c|}
\hline Method & Group & $\begin{array}{l}\text { No. of } \\
\text { rabbits }\end{array}$ & \begin{tabular}{llllllllllll}
\multicolumn{1}{c}{ Day } \\
1 & 2 & 3 & 4 & 5 & 6 & 7 & 8 & 9 & 10 & 11 & 12
\end{tabular} & $\begin{array}{l}\text { Daily dosis of } \\
\text { cortisone }\end{array}$ \\
\hline No. 9 & $\begin{array}{l}\mathrm{A} \\
\mathrm{B} \\
\mathrm{C} \\
\mathrm{D}\end{array}$ & $\begin{array}{l}20 \\
12 \\
16 \\
10\end{array}$ & 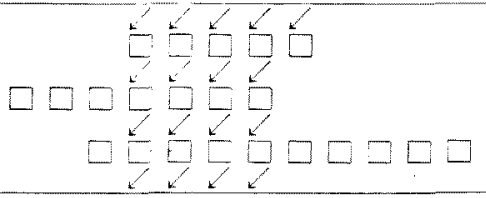 & $\begin{array}{l}1.0 \sim 10.0 \mathrm{mg} \\
1.0 \sim 12.5 \mathrm{mg} \\
1.0 \sim 12.5 \mathrm{mg} \\
-\end{array}$ \\
\hline No. 3 & $\begin{array}{l}\mathrm{E} \\
\mathrm{F}\end{array}$ & $\begin{array}{r}14 \\
8\end{array}$ & $\square \square \leftleftarrows \square \square \square \square \square \square$ & $\begin{array}{c}2.5-50.0 \mathrm{mg} \\
-\end{array}$ \\
\hline
\end{tabular}

D: Cortisone in jection.

$\Sigma^{\prime}$ : Injection of Str. sanguis \& antiserum/phosphatide.

Each group, except for the control group, was furthe: divided according to the doses of cortisone. In another method, cortisone was given for eleven days, beginning 2 days before the first injection of phosphatide and Str. sanguis. Ten $\mathrm{mg}$ of rabbit brain phosphatide and $0.7 \mathrm{ml}$ of Str. sanguis suspension were injected 4 times every other day. The results obtained were shown in Figure 2. Development of an endocarditis seemed to be prevented by $2.5 \mathrm{mg}$ prodie of cortisone in groups $\mathrm{B}$ and $\mathrm{C}$ and by $5.0 \mathrm{mg}$ in Group $\mathrm{E}$. Mortality rate was

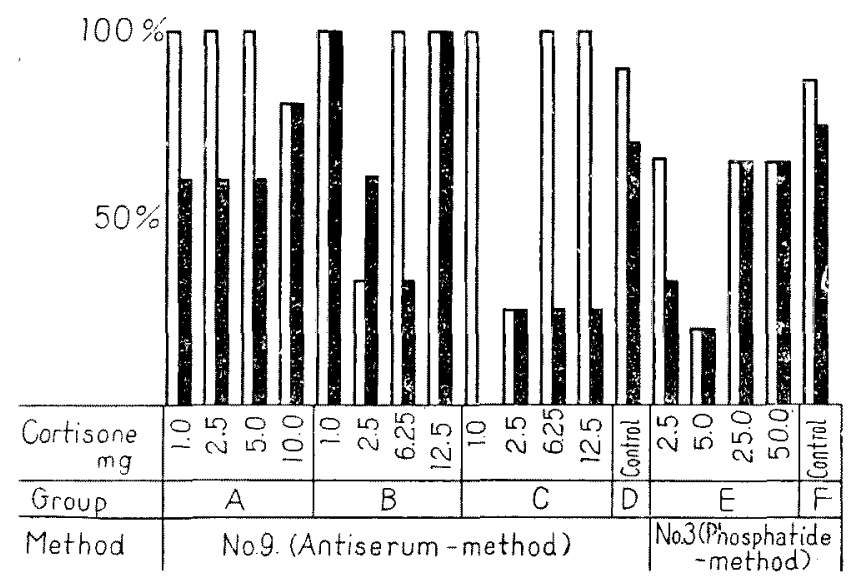

Fig. 2 Incidence of produced endocarditis (open bars) and mortality (solid bars) in each group. 
lower in $6.25 \mathrm{mg}$ cortisone of group $\mathrm{B}$, in all of group $\mathrm{C}$ and in $2.5 \mathrm{mg}$ and $5 \mathrm{mg}$ of Group E. From this it may be assumed that in some doses, cortisone may be effective to prevent the disease, though the amount is not fixed but depends on experimental method. I think, it is also note-worthy that a preventive effect was noted in groups $\mathrm{B}, \mathrm{C}$ and $\mathrm{E}$ where cortisone injection was begun preceding the indueing injections, and that mortality rate was low in group $\mathrm{C}$ and $\mathrm{E}$ in which the duration of cortisone injections was longer.

\section{HISTOLOGICAL LESIONS OF EXPERIMENTAL BACTERIAL ENDOCARDITIS}

\section{a) Survey of the Literatures}

Various views have been set forth by many investigators on the histological lesions in the development of bacterial endocarditis, and Table 4 shows the representative ones, which can be divided into two categories: 1) lodging of a thrombus from the blood stream onto the endocardial cells previously damaged

Table 4

Vicw on Histalogical Figures of Bacterial Endocarditis

\begin{tabular}{|c|c|c|c|c|}
\hline & \multirow{3}{*}{$\begin{array}{l}\text { View that regards a } \\
\text { minute thrombus stuck } \\
\text { to the endothel as ini- } \\
\text { tial lesion }\end{array}$} & Attaching importance to & Advocated by & in \\
\hline & & a. Endocardial damage & $\begin{array}{l}\text { Rosenbach } \\
\text { Kaufmann } \\
\text { Nabeshima } \\
\text { Kinsella }\end{array}$ & $\begin{array}{l}1878 \\
1922 \\
1932 \\
1938\end{array}$ \\
\hline & & $\begin{array}{l}\text { b. Phagocytosis of endo- } \\
\text { thelial cells }\end{array}$ & Dietrich & 1926 \\
\hline & \multirow[t]{2}{*}{$\begin{array}{l}\text { View that initial lesion } \\
\text { occurs in the valvular } \\
\text { tissue }\end{array}$} & $\begin{array}{l}\text { a. Reactivity of the sub- } \\
\text { endothelial layer }\end{array}$ & $\begin{array}{l}\text { Klinge } \\
\text { Siegmund } \\
\text { Apitz } \\
\text { Ishibashi } \\
\text { Beisch \& Böhmig }\end{array}$ & $\begin{array}{l}1929 \\
1933 \\
1933 \\
1933 \\
1950\end{array}$ \\
\hline & & $\begin{array}{l}\text { b. Newly formed blood } \\
\text { vessels in the valve }\end{array}$ & Gross \& Fried & 1937 \\
\hline
\end{tabular}

by a certain causes may be the starting point of the initial lesion of endocarditis;

2 ) and the initial lesion is already existent in the valvular tissue when a thrombus lodges there.

\section{b) Our View from the Experiments}

After histological studies of the rabbits and rats with experimental bacterial endocarditis, killed day by day with progression, we have developed a schema showing different figures from early stages toward completion of the disease (Fig. 3). 


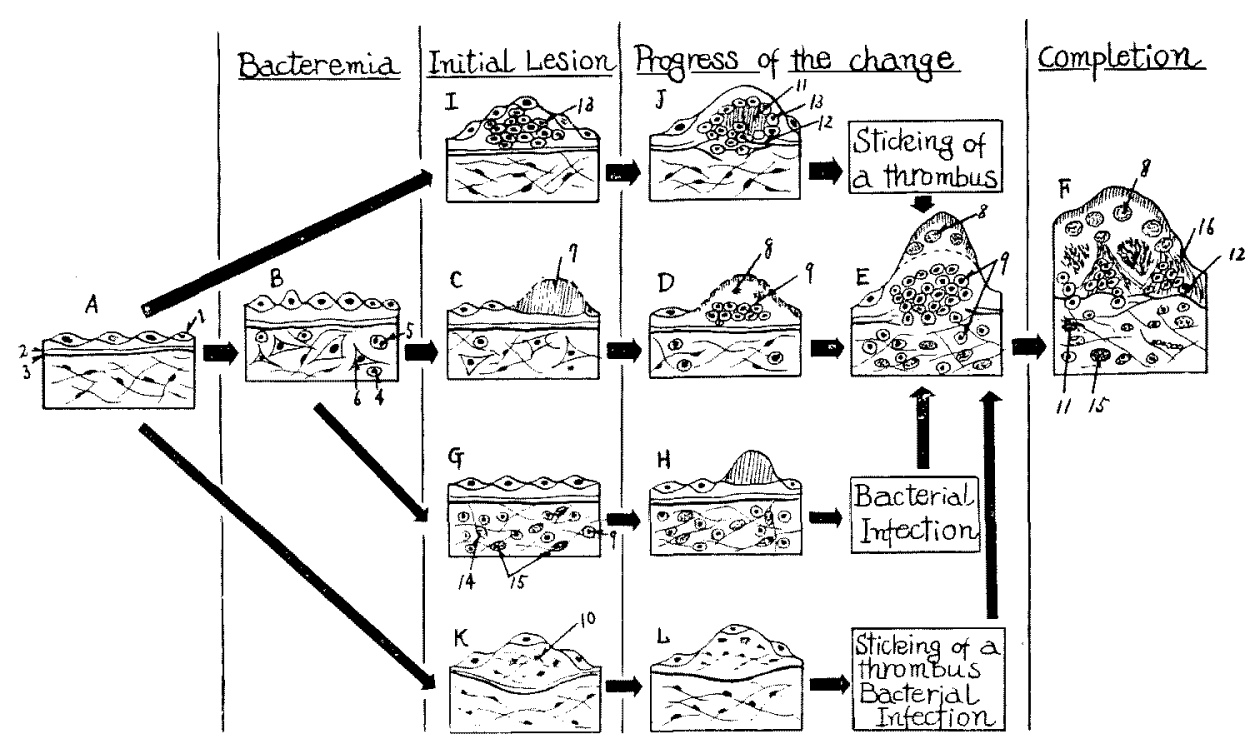

Fig. 3 Schema of histological figures in developing bacterial endocarditis, worked out from our experimental data.

A : Normal valve

B: Swelling and edema of the endothel, swollen fibrocytes, diffuse valvulitis

C: Sticking of a minute thrombus

$D$ : Bacterial infection into the thrombus and cullular infiltration in it

E: Formation of vegetation and ulceration, enlargment of the infected thrombus and enforced cellular infiltration

$G$ : Diffuse valvulitis

$\mathrm{H}$ : Sticking of a thrombus

I: Proliferation of histiocytes in the sub. endothelial layer

$\mathrm{J}$ : Productive verruca and fibrinoid substance

$\mathrm{K}$ : Serous inflammation (Böhmig)

$\mathrm{L}$ : Fibrinous inflammation (Böhmig)
1. Endothel cell

2. The lamina propria

3. The lamina elastica

4. Lymphocyte

5. Leucocyte

6. Fibrocyte

7. Platelet thrombus

8. Colony of the causative microorganisms

9. Cellular infiltration

10. Degenerated nucleus of fibrocyte

11. Fibrinoid substance

12. Destroyed elastic fibers

13. Proliferation of histiocytes

14. Hypertrophy of fibrocytes

15. Newly formed blood vessel

16. Organized thrombus

First we injected rabbits brain phosphatide and living Str. sanguis suspension respectively as a control group and observed histological changes. Within five days after injection of rabbits brain phosphatide only to rabbits, there were mild changes such as edema in endocardium or swelling of endothelial cells, but after injection of living Str. sanguis suspension only every other day, we observed early changes or mild degree of valvulitis.

Within 48 hours after injection of Str. sanguis, as a result of the bacteremia, a slight valvulitis with hypertrophy of the endothelial cells is noticed (B in Fig. 3). Subsequently, as an initial lesion of endocarditis, a minute 
platelet thrombus on the endothelium (C), a proliferation of histiocytic cells localized in the subendothelial laver (I), a change called Boehmig's serous inflammation $(K)$ or a slight diffuse valvulitis especially in rats $(G)$ develops. In four or five days with later progression of each change, a thrombus formed on the surface of the valve increases in size, and some colonies of the streptococcus become visible in it. Then, the lamina elastica is damaged by active proliferation of fibrocytes and cellular infiltration, and thus a bacterial endocarditis is completed.

Here we can estimate the time of bacterial infection into the valve, since we could first find Gram-positive microorganisms in the platelet thrombus of (D) and fibrinoid substance of $(J)$, and not in the preceding stages. The process from (B) to $(F)$ coincides with the first view that regards a thrombus stuck to the endothelium as an initial lesion, and the process from (I) to (F) with the second view that regards a tissue reaction in the subendothelial layer as an initial lesion. The one from $(K)$ to $(F)$ is consistent with Böhmig's theory which belongs to the latter view.

It is very important that we could find these four different types in early changes produced by the same method of experiment. Now we can understand that each of the former investigators put forward their own view by observing only one of these types.

In all cases, these initial lesions always occur outside the elastica and the basal membrane, and upon these lesions a thrombus containing bacterial colonies is formed. Then inflammatory reaction from inside of the valve presses on the elastica, resulting in its destruction. Thereafter there is only one mode to. completion of endocarditis.

Though there is no relation between types of an initial lesion or early changes and a method employed to produce an endocarditis, those factors such as cardiac distress, change in blood components, allergic factor, etc. are likely to have some influence on the endotherial cells and the subendothelial tissues of the valve to foster an onset of an initial lesion then a completion of endocarditis.

\section{EXPERIMENTS ON THERAPEUTIC EFFECTS}

\section{a) With a Single Use of Antibiotic}

Leucomycin, penicillin and streptomycin were independently tested in the treatment of experimentally induced bacterial endocarditis of rabbits. Improvement of the general symptoms was noted by the daily administration of more than 300,000 units of penicillin, or of over $125 \mathrm{mg}$ of streptomycin. Most of 
the rabbits treated with penicillin showed negative blood or organ cultures. Mortality rate was the lowest in the streptomycin group (over $125 \mathrm{mg}$ ). The survival period was shortest in the penicillin 100,000 units group. It was prolonged in the leucomycin and the streptomycin groups (Table 5).

Table 5

Therapeutic Effects of Lencomycin, Peniciblin and Streptomycin in Single use

\begin{tabular}{|c|c|c|c|c|c|}
\hline $\begin{array}{l}\text { Antibiotic used } \\
\text { daily dosis }\end{array}$ & $\begin{array}{c}\text { No. } \\
\text { of } \\
\text { rabbits }\end{array}$ & $\begin{array}{c}\text { Improvement } \\
\text { of symptoms } \\
(0)\end{array}$ & $\begin{array}{c}\text { Positive } \\
\text { culture } \\
\text { blood/organ } \\
\left(0_{0}\right)\end{array}$ & $\begin{array}{c}\text { Mortality } \\
\text { rate } \\
\left(0_{0}\right)\end{array}$ & $\begin{array}{l}\text { Average } \\
\text { survival } \\
\text { days }\end{array}$ \\
\hline $\begin{array}{l}\text { Leucomycin } \\
100 \sim 200 \mathrm{mg} \quad 10 \text { days }\end{array}$ & 7 & 43 & 47 & 43 & 19 \\
\hline $\begin{array}{l}\text { Penicillin } \\
100,000 \mathrm{u}\end{array}$ & 4 & 25 & 5 & 75 & 6 \\
\hline 300,000 u. $\quad 5$ days & 16 & 81 & 9 & 56 & 12 \\
\hline $\begin{array}{l}\text { Streptomycin } \\
\text { less than } 100 \mathrm{mg} \\
\qquad 10 \text { days }\end{array}$ & 8 & 63 & 75 & 50 & 19 \\
\hline over $125 \mathrm{mg} 10$ days & 12 & 75 & 35 & 0 & 22 \\
\hline
\end{tabular}

Histological lesions of every group were investigated from the standpoint of therapeutic effects, especially studied from the point of disappearances of bacteria in the thrombus (by Gram stain), organization and fibrosis in the basal and peripheral parts of the thrombus (Hematoxylin-Eosine and Mallory's stain), regeneration of endothelial cells on the surface of the thrombus and cellular infiltration in the tissue, decreasing in leucocytes and increasing in small round cells.

Judging from these findings, those animals treated with other $125 \mathrm{mg}$ of streptomycin showed well-developed organization and fibrosis of the thrombus and almost complete disappearance of the bacteria in the vegetation. Treatment with less than $100 \mathrm{mg}$ of streptomycin was ineffective, and penicillin was slightly effective. The effect of leucomycin was indefinite.

b) With a Combined Use of Penicillin and Streptomycin

Combined therapy of 100,000 units of penicillin and $125-250 \mathrm{mg}$ of streptomycin for ten days showed definitely better effect than the control group. When we compared this group treated with combined therapy to a group administered 300,000 units of penicillin for ten days, it showed about same rate of culture but it had improved mortality rate which was somewhat worse than the one with streptomycin treatment alone. From these result, it doesn't seem to be antagonistic action in the combined therapy even though we can't say that the combined therapy is better than the single treatment. 
c) With a Combined Use of Steroid Hormones and Antibiotics

1. Penicillin and Cortisone Therapy:-As shown in Table 6, we gave

Table 6

Effect of Cortisone upon Treatment wuith Penicillin

\begin{tabular}{|c|c|c|c|c|c|c|c|c|c|c|c|c|c|}
\hline \multirow{2}{*}{ Group } & \multirow{2}{*}{$\begin{array}{l}\text { No. of } \\
\text { rabbits }\end{array}$} & \multicolumn{10}{|c|}{ Day } & \multirow{2}{*}{$\begin{array}{l}\text { Dosis of } \\
\text { cortisone }\end{array}$} & \multirow{2}{*}{$\begin{array}{l}\text { Dosis of } \\
\text { penicillin }\end{array}$} \\
\hline & & 1 & 2 & 3 & 4 & 5 & 6 & 7 & 8 & 9 & 10 & & \\
\hline A & 3 & $\square$ & {[} & C & 0 & $\square$ & $\square$ & D & $\square$ & $\square$ & $\square$ & $5 \mathrm{mg} \times 10^{\text {days }}$ & - \\
\hline B & 5 & $\begin{array}{l}P_{c} \\
\square\end{array}$ & $P_{c}$ & Pc & $\mathrm{Pe}$ & $\mathrm{Pc}$ & $\square$ & $\square$ & $\square$ & $\square$ & $\square$ & $5 \mathrm{mg} \times 10$ & $300.000 \times 5$ \\
\hline $\mathrm{C}$ & 5 & $\leftarrow \square$ & $\frac{\mathrm{Pc}}{\mathrm{C}}$ & $\begin{array}{l}\mathrm{Pc} \\
\mathrm{C}\end{array}$ & $\mathrm{Pc}$ & $\mathrm{Pc}$ & $\square$ & $\square$ & $\square$ & $\square$ & $\square$ & $25 \mathrm{mg} \times 10$ & $300,000 \times 5$ \\
\hline $\mathrm{D}$ & 8 & $\mathrm{Pc}$ & $\mathrm{Pc}$ & $\mathrm{Pc}_{\mathrm{c}}$ & $\mathrm{Pc}$ & $\mathrm{Pc}$ & & & & & & - & $300.000 \times 5$ \\
\hline $\mathrm{E}$ & 8 & 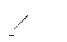 & & & & & & & & & & - & - \\
\hline
\end{tabular}

Cortisone injection.

$\checkmark$ : The last injection of. Str. sanguis \& phosphatide.

cortisone, $5 \mathrm{mg}$ in Group $\mathrm{A}$ and $\mathrm{B}, 25 \mathrm{mg}$ in Group $\mathrm{C}$ for ten days, and treatment with 300,000 units of procain penicillin was given for five days in Group $\mathrm{B}, \mathrm{C}$ and D. In Group B sufficient amount of penicillin and $5 \mathrm{mg}$ of cortisone were used for treatment and yielded better results than group $\mathrm{D}$ which was treated with penicillin alone. Group $\mathrm{C}$ in which a surplus amount of cortisone was given with penicillin therapy produced the worst results (Table 7).

Table 7

Therapeutic Responces by Penicillin and cortisone in each Group

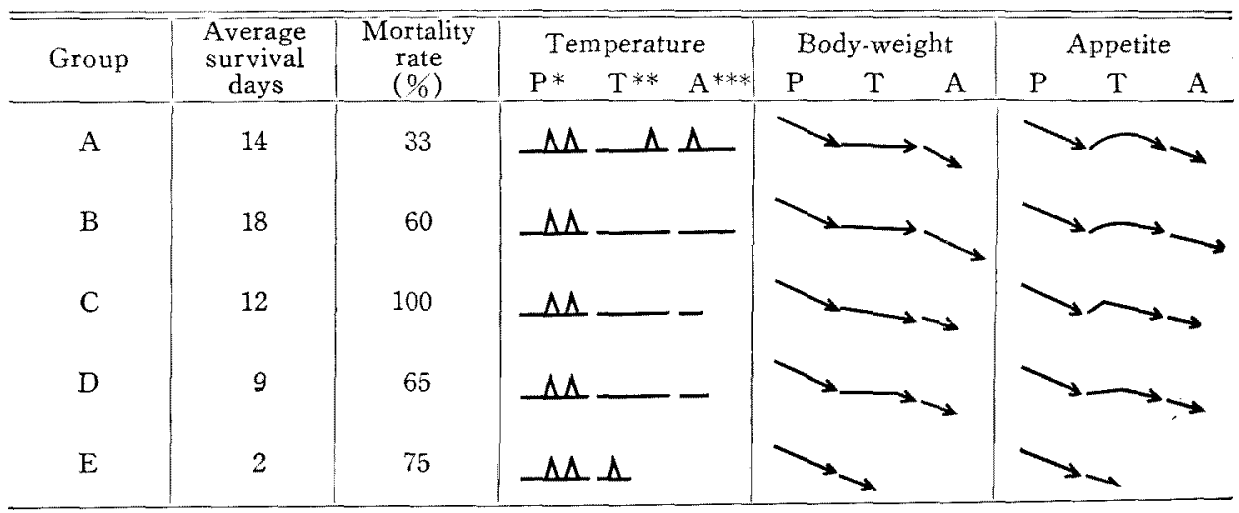

* P: During preliminary injections to induce endocarditis, i.e. before treatment.

** T: During treatment.

*** A : After treatment.

2. Cases When We Stopped the Treatment of Penicillin and Cortisone at the Same Time and When We Continued Penicillin Only:-As is obvious from Table 8 , the latter is superior with regards to per cent of positive culture from 
Table 8

Two Different Methods of Pc and Cortisone Treatment

\begin{tabular}{l|c|c|c|c|c|c}
\hline \multicolumn{1}{c|}{ Group } & $\begin{array}{c}\text { Method } \\
\text { of } \\
\text { administ. }\end{array}$ & $\begin{array}{c}\text { No. of } \\
\text { rabbits }\end{array}$ & $\begin{array}{c}\text { Weight } \\
\text { Loosing } \\
(\%)\end{array}$ & $\begin{array}{c}\text { Positive } \\
\text { culture } \\
\text { blood/org. }\end{array}$ & $\begin{array}{c}\text { Mortality } \\
\text { rate } \\
(\%)\end{array}$ & $\begin{array}{c}\text { Average } \\
\text { survival } \\
\text { days }\end{array}$ \\
\hline $\begin{array}{l}\text { Pc \& cortisone } \\
\text { were } \\
\text { discontinued } \\
\text { at the same time }\end{array}$ & $\begin{array}{l}\mathrm{Cs} \\
\mathrm{Pc}\end{array}$ & 24 & 55 & 34 & 88 & 14 \\
\hline $\begin{array}{l}\text { Pc was continued } \\
\text { after discontinuat. } \\
\text { of cortisone }\end{array}$ & $\begin{array}{l}\mathrm{Cs} \\
\mathrm{Pc}\end{array}$ & 27 & 30 & 17 & 62 & 22 \\
\hline
\end{tabular}

organs, mortality rate and average survival days.

3. Combined Treatments of Penicillin and Prednisolone (Penicillin 300,000 units, Prednisolone 1.0-0.25 mg.):-As shown in Table 9, for the group that

Table 9

Single and Combined Therapy with Pc and Prednisolone in Different Terms

\begin{tabular}{|c|c|c|c|c|c|c|}
\hline Group & Method of administrat. & $\begin{array}{l}\text { No. of } \\
\text { rabbits }\end{array}$ & $\begin{array}{l}\text { Weight- } \\
\text { Loosing } \\
(0)\end{array}$ & $\begin{array}{l}\text { Positive cul- } \\
\text { ture from } \\
\text { organ }(\%)\end{array}$ & $\begin{array}{c}\text { Mortality } \\
\text { rate } \\
(\%)\end{array}$ & $\begin{array}{c}\text { Average } \\
\text { survival } \\
\text { days }\end{array}$ \\
\hline $\begin{array}{l}\text { Combined } \\
\text { treat } \\
\text { (long term) }\end{array}$ & $\begin{array}{ll}\text { PSL } & 20 \\
\mathrm{Pc} & \square \text { days }\end{array}$ & 1 & 50 & 65 & 100 & 17 \\
\hline $\begin{array}{c}\text { Combined } \\
\text { treat } \\
\text { (short term) }\end{array}$ & $\begin{array}{l}\text { PSL } \square \text { days } \\
\text { Pc } \square 10 \text { days }\end{array}$ & 15 & 13 & 48 & 73 & 22 \\
\hline \multirow{2}{*}{$\begin{array}{l}\text { Single } \\
\text { method }\end{array}$} & $\operatorname{Pc} \overline{\frac{15 \sim 20}{} \text { days }}$ & 12 & 25 & 62 & 83 & 20 \\
\hline & PSL $\square 5$ days & 6 & 50 & 100 & 100 & 4 \\
\hline
\end{tabular}

penicillin and prednisolone were combined for 20 days, the results were unfavorable in every respects when we compare it to the group that penicillin for 10 days and prednisolone for 5 days were combined, even when penicillin was injected for 10 days longer period to the former. It might be possible to conclude that it is impossible to continue the combination therapy for more than certain periods. The latter showed better result than group which we gave penicillin alone.

4. Method of Administration:-We have defined the three types in Table 10 as follows:

1. To start both penicillin and prednisolone at the same time.

2. To start penicillin first then prednisolone 
Table 10

Three Different Methods of $P_{C}$ and Prednisolone (PSL) Treatment

\begin{tabular}{|c|c|c|c|c|c|c|}
\hline Group & $\begin{array}{l}\text { Method of com- } \\
\text { bined treatment }\end{array}$ & $\begin{array}{l}\text { No. of } \\
\text { rabbits }\end{array}$ & $\begin{array}{l}\text { Weight- } \\
\text { Loosing } \\
(00)\end{array}$ & $\begin{array}{c}\text { Positive } \\
\text { culture from } \\
\text { organ } \\
(90)\end{array}$ & $\begin{array}{c}\text { Mortality } \\
\text { rate } \\
(0)\end{array}$ & $\begin{array}{l}\text { Average } \\
\text { survival } \\
\text { days }\end{array}$ \\
\hline I type & $\begin{array}{l}\text { PSL } \square \\
\text { Pc } \square\end{array}$ & 6 & 0 & $\pi 7$ & 83 & 18 \\
\hline II type & $\begin{array}{l}\text { PSL } \\
\text { Pc }\end{array}$ & 7 & 14 & 40 & 71 & 20 \\
\hline III type & $\begin{array}{l}\text { PSL } \\
\operatorname{Pc}\end{array}$ & 8 & 50 & 90 & 100 & 7 \\
\hline
\end{tabular}

3. To start prednisoloen first and then penicillin when prednisolone is still applied, and stop the treatment of penicillin before we discontinue prednisolone.

Among these 3 , the group 3 generally showed unfavorable result, substantial difference was not observed between 1 and 2 .

5. Combination of Penicillin and Hydrocortisone (2.5-25 $\mathrm{mg}$ for ten days):-According to this finding, it doesn't seem to give special combination effect.

6. Combination of penicillin and $\mathrm{ACTH}(0.2-20 \mathrm{mg}$ for ten days $)$; The

Tab!e 11

Effect of DOCA on PC Treatmont

\begin{tabular}{c|c|c|c|c|c}
\hline Group & $\begin{array}{c}\text { Method of } \\
\text { administrat. }\end{array}$ & No. of rabbits & $\begin{array}{c}\text { Weight- } \\
\text { Loosing } \\
\left(0_{0}\right)\end{array}$ & $\begin{array}{c}\text { Mortality } \\
\text { rate } \\
(\%)\end{array}$ & $\begin{array}{c}\text { Average } \\
\text { survival } \\
\text { days }\end{array}$ \\
\hline $\begin{array}{c}\text { Control } \\
\text { (Bacterial } \\
\text { strain alone }\end{array}$ & DOCA & 5 & 60 & 100 & 17 \\
\hline $\begin{array}{c}\text { DOCA } \\
\text { alone }\end{array}$ & 11 & 61 & 64 & 16 \\
\hline $\begin{array}{c}\text { Pc } \\
\text { alone }\end{array}$ & Pc & 8 & 88 & 88 & 15 \\
\hline $\begin{array}{c}\text { DOCA, Pc } \\
\text { combination }\end{array}$ & $\begin{array}{l}\text { POCA } \\
\text { Pc }\end{array}$ & 18 & 89 & 72 & 19 \\
\hline
\end{tabular}


special effects were not observed here either.

7. Combination of penicillin and DOCA $(0.02-2.0 \mathrm{mg}$ for five days):As one can observe in Table 11, we cannot recognize an unfavorable effect when we combined penicillin and DOCA, compared the group when only penicillin was used. Even for the group penicillin and DOCA were combined, we can observe a favorable influence on the general condition.

d) Treatment of Endocaritis Caused by Streptomycin-resistant Strain of Streptococcus sanguis

Streptomycin resistant strain of Str. sanguis was used to cause an experimental bacterial endocarditis. As shown in Table 12, endocarditis caused by it

Table 12

Bacteria' Endocarditis Caused by Stroptomycin-Resistant Struin and Sensitive Strain, Treated with 125 250 mg of Streptomycin for 10 Days

\begin{tabular}{c|c|c|c|c|c}
\hline \hline Caused by & $\begin{array}{c}\text { No. of } \\
\text { rabbits }\end{array}$ & $\begin{array}{c}\text { Improvement } \\
\text { of Symptoms } \\
(0 .)\end{array}$ & $\begin{array}{c}\text { Positive } \\
\text { Culture blood } \\
\text { organ }(0 \%)\end{array}$ & $\begin{array}{c}\text { Mortality } \\
\text { rate } \\
(\%)\end{array}$ & $\begin{array}{c}\text { Average } \\
\text { Survival } \\
\text { days }\end{array}$ \\
\hline $\begin{array}{c}\text { Streptomycin } \\
\begin{array}{c}\text { Sensitive Strain } \\
25 \gamma \mathrm{cc}\end{array}\end{array}$ & 12 & 75 & 35 & 0 & 22 \\
$\begin{array}{c}\text { Resistant Strain } \\
5000 \gamma \mathrm{cc}\end{array}$ & 18 & 39 & 62 & 33 & 2 \\
\hline
\end{tabular}

did not respond well to streptomycin treatment, this fact was also proved by histological studies. Sensitivity of the organism isolated from a diseased rabbit one month after the onset of endocarditis and treatment was examined and it was shown to be as resistant as the original strain.

The results obtained in this series of experiments are summarized as follows:

1. The streptomycin resistant strain can cause an endocarditis in rabbit similar to the sensitive ones.

2. Virulence of the resistant strain is stronger than that of the sensitive strain.

3. Endocarditis by the resistant strain does not respond to streptomycin.

4. Resistance did not change in vivo after one month.

\section{RECONSIDERATION ON ANTIBIOTIC THERAPY}

In spite of larger doses of antibiotic than that usually used clinically, therapeutic effect in the above experiments was not always satisfactory. In order to explain this observation, some experiments were made. 
a) Experiment Using Streptococcus mitis

In all of the above experiments we used a strain of Str. sanguis that has been reported to cause a hardly curable endocarditis in human, but here a strain of Str. mitis, a common cause of human endocarditis, was employed. Only one rabbit out of 8 infected with Str. mitis developed endocarditis. It was well cured by streptomycin.

Therefore, we can say it is not due to the ineffectiveness of the antibiotics, but due to the resistance of Str. sanguis used to produce the endocarditis that prevented cure in our experimental endocarditis.

b) Therapeutic Effect Judging from Size of Vegetation

Juding from the size of the vegetations seen in the valve, the rabbits which had a vegetation of bean size showed $100 \%$ mortality, positive blood or organ cultures and evidences of venous congestion such as hepatomegaly and pleural or peritoneal fluid, regardless to kind or dosage of drugs. On the other hand, the rabbits with miliary or smaller vegetations showed a very low death-rate, few positive cultures and no evidence of congestion.

From this, it will be obvious that we can not expect satisfactory effectiveness of antibiotics if a vegetation has already grown beyond a certain size. We know how difficult it is to eradicate bacteria in a vegetations since positive cultures were obtained from large vegetations, while cultures of the heart blood were negative.

Table 13

Hemodynamics of a Dog with Experimental Endocarditis Studied By Cardiac Catheterization

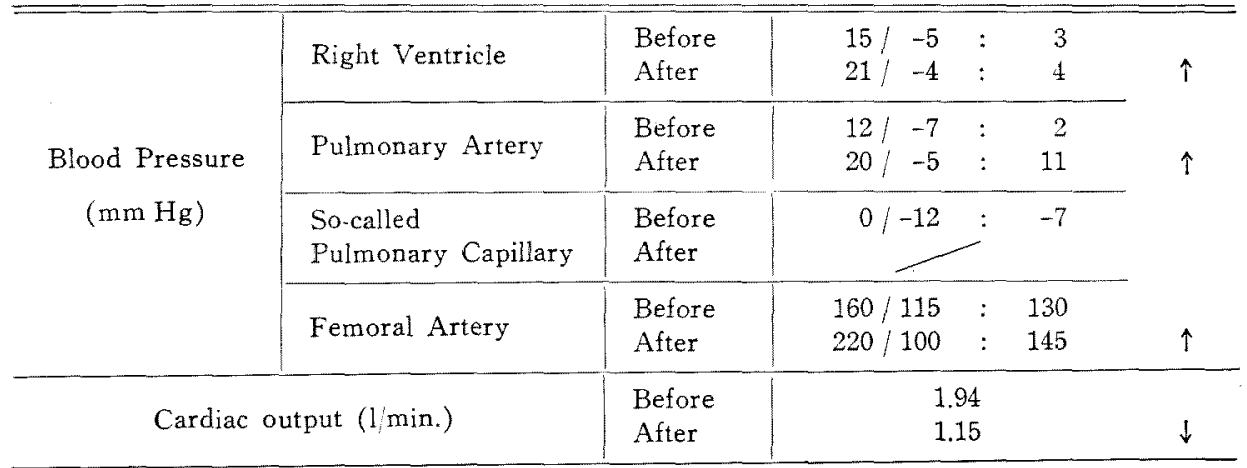

Table 13 shows the hemodynamies of a dog with experimentally produced endocarditis with using cephalin and Str. sanguis investigated by cardiac catheterization. This dog had a large vegetation on the aortic and mitral 
valves. Hypertension in the right ventricle, pulmonary artery and femoral artery and decrease in cardiac output etc. were noticed. These data coincide well with the congestion that appeared in the rabbit with bean-size vegetation above mentioned.

\section{DISCUSSION ESPECIALLY IN REFERENCE TO CLINICAL ASPECTS}

From our experiments above mentioned, we have many important evidences from which the pathogenesis or pathological (histological) processes of human endocarditis can be analogized. We could damage the valve of rabbit beforehand and succeeded in producing endocarditis upon it. Therefore, we believe that the methods we tested successfully using rabbits can be available for further investigation of pathogenesis or other problems.

At autopsy we have found that there were mixtures of healing processes and fresh active foci in experimental endocarditis treated with antibiotics, and this is just the same as we often experimence in human cases.

As to use of hormones of the pituitary-adrenal system for treatment of subacute bacterial endocarditis, many problems still remain unsolved. We can not decide conclusively without cautious consideration. The only thing we can say now from our experiments is that a certain amount of cortisone may be effective for prevention of the disease and when used combined hormones of the pituitary-adrenal system with antibiotics. Subacute bacterial endocarditis has showed definite effect on the treatment both new and old lesions at the same time as mentioned; and therefore, the amount, the phase, and duration, if hormone therapy using the pituitary adrenal system is attempted, must be well considered in preventive and therapeutic senses.

Streptococcus sanguis, a sub-type of Str. viridans, has already been known as an annoying causative agent of subacute bacterial endocarlitis, and it was proved also by experiment. Therefore, it is very important to detect a sub-type of Str. viridans as early as possible, and the precipitation-reaction we reported before is quite helpful for it. It is our future responsibility to solve the problem why endocarditis caused by Str. sanguis is so difficult to cure and to find a satisfactory therapeutic method and regimen for it.

When a vegetation became larger than a given size, all of the animals could not be cured, regardless of chemotherapeutics employed. This seems to mean that some effective treatment is absolutely necessary in the early stages of subacute bacterial endocarditis that causes a destruction and deformity of the valve without fail, in order to prevent the formation of large verruca. The animals which manifested signs or symptoms of congestive heart failure, includ- 
ing the dog examined by catheterization, died after a protracted course of the disease under chemotherapy. This phenomenon coincides with that in human cases.

We have previously stressed that prevention and treatment against cardiac failure are as important as antibiotic therapy against infection in treatment of subacute bacterial endocarditis.

\section{BIBLIOGRAPHY}

1. Böhmig, R. \& Klein, P.: Pathologie und Bakteriologie der Endokarditis. SpringerVerlag, Berlin, Göttingen, Heidelberg, 1953.

2. Clawson, B. L.: Experimental Endocarditis in Normal Animals and in Animals treated with Cortisone. Arch. Path. 56: 269, 1953.

3. Gould, S. E.: Pathology of the Heart. Charles C. Thomas, Publisher, Springfield, Illinois, U.S.A., 1953.

4. Highman, B. \& Altland, P. D.: a) Acclimatization Response and Pathologic Changes in Rats at an Altitude of 25,000 Feet. Arch. Path. 48: 503, 1949; b) A New Method for Production of Experimental Endocarditis. Proc. Soc. Exp. Biol. \& Med. 75: 573, 1950; c) Experimental Bacterial Endocarditis in Altitude Rats. II. Shorting Acclimatization Period. Proc. Soc. Exp. Biol. \& Med. 78: 590, 1951; d) Effects of Altitude and Cobalt Polycythemia, Hypoxia, and Cortisone on Susceptibility of Rats to Endocarditis. Circulation Research 3: 351, 1955.

5. Highman, B., Altland, P. D., \& Eagle, H.: Experimental Bacterial Endocarditis in Altitude Rats. Pathologic Lesions and Effect of Penicillin Therapy. Am. J. Path. 29: $593,1953$.

6. Hoshino, H.: Studies of Experimental Bacterial Endocarditis. Keio Igaku 33: 564, 1956. (in Japanese).

7. Katsu, M.: Use of Adrenocorticosteroids and $\mathrm{ACTH}$ in Combination with Antibiotics in Infectious Diseases. Chemotherapy 6:265, 1958. (in Japanese).

8. Mikata, I.: a) Clinical Aspects of Subacute Bacterial Endocarditis. Nanzando, Tokyo, Japan. 1955 (in Japanese). b) Experimental Bacterial Endocarditis with Special Reference to Clinical Aspects. The Japanese Circulation J. 21: $1,1957$.

9. Mikata, I., Katsu, M., \& Hasunuma, I.: Pathogenesis of Subacute Bacterial Endocarditis. Saishinigaku, 10: 2447, 1955. (in Japanese).

10. Mikata, I., Narita, K., \& Murakami, S.: Experimentale bak'serielle Endokarditis; über Wirkung und Bedeutung von Phosphatid. Münch. Wschr. 98: 1034, 1957.

11. Narita, K. et al.: Studies of Experimental Bacterial Endocarditis. Hyogo Pref. Med. J. 1: 1, 1953. (in Japanese).

12. Onuki, H.: Drug Resistance Acquired by Experiment of Streptococcus sanguis, especially about Cross-resistance. J. Jap. Ass. Infect. Dis. 32: 114, 1958. (in Japanese).

13. Yamada, T.: Studies of Experimental Bacterial Endocarditis produced by AntiRabbit-Endocardium Duck Serum. 1953. (in Japanese). 